\title{
URBAN ENVIRONMENT USE BY SPECKLED (COLUMBA GUINEA) AND FERAL (COLUMBA LIVIA) PIGEONS ON THE UNIVERSITY OF SOUTH AFRICA'S MUCKLENEUK CAMPUS
}

\author{
HARris, E..$^{{ }^{*}}$ - DE CROM, E. P. ${ }^{2}$ - Labuschagne, J. ${ }^{3}-$ Wilson, A. ${ }^{4}$ \\ ${ }^{1}$ Applied Behavioural Ecology and Ecosystem Research Unit (ABEERU), Department of \\ Agriculture and Environmental Sciences, University of South Africa \\ Private Bag X6, Florida, 1710, RSA \\ ${ }^{2}$ Department of Nature Conservation, Tshwane University of Technology \\ Private Bag X680, Pretoria, 0001, RSA \\ (phone: +27-12-382-4194; decromep@tut.ac.za) \\ ${ }^{3}$ Department of Environmental Sciences, University of South Africa \\ Private Bag X6, Florida, 1710, RSA \\ (phone: +27-11-471-2321; JP.Labuschagne@gmail.com) \\ ${ }^{4}$ Applied Behavioural Ecology and Ecosystem Research Unit (ABEERU), Department of \\ Agriculture and Environmental Sciences, University of South Africa \\ Private Bag X6, Florida, 1710, RSA \\ (phone: +27-11-471-2800; cheata@unisa.ac.za) \\ *Corresponding author \\ e-mail: harrie1@unisa.ac.za \\ (phone: $+27-11-471-2321$ ) \\ (Received 29 $9^{\text {th }}$ Apr 2016; accepted $21^{\text {st }}$ Jul 2016)
}

\begin{abstract}
A study on a population of speckled Columba guinea and feral Columba livia pigeons on the University of South Africa's (UNISA) Muckleneuk campus was conducted from March 2013 to February 2014. Morning and evening counts, once a week, were conducted by an observer who also noted the presence of breeding activity and the use of ledges in relation to aspect and levels of buildings. The pigeon population index fluctuated seasonally. Breeding occurred throughout the year, with notable peaks and declines relating to physiological and population dynamics. Opportunistic use of the crop availability was made during optimal production periods, while conserving energy when not favourable. Site selection in relation to building aspect indicated significant differences in all the seasons except for winter, while a positive significant relationship between level height and pigeon numbers was recorded. Knowledge of pigeon ecology and their use of urban landscapes contribute to further understanding wildlife management.
\end{abstract}

Keywords: pigeons; agricultural availability; ledge use; aspect choice; urban environments

\section{Introduction}

Separated by genetic variation, speckled pigeons (Columba guinea Linnaeus, 1758) and feral pigeons (Columba livia Gmelin, 1789) (hereafter referred to collectively as pigeons) (Stringham et al., 2012) have for centuries populated urban environments worldwide (Robbins, 1995). The species has had to adapt to the expanding urban sprawl by learning to cohabit with human lifestyles to supplement and ensure their own survival (Fitzwater, 1988). Their ability to adjust through behavioural, physiological (Shochat et al., 2010) and life-history strategy changes (Ditchkoff et al., 2006) has enabled the species to successfully colonise and adapt to abundant food and water 
resources, choose nesting and roosting sites (Bolger, 2001; Hadidian, 2007; Krimowa, 2012), select milder micro-climates (Jokimäki et al., 2005) and fewer predators (Tigas et al., 2002; Hadidian, 2007; Tsurim et al., 2008) in new and unfamiliar habitats (Luniak, 2004; Shochat et al., 2010). Changes in social and spatio-temporal strategies of the species have resulted in an estimated global occurrence of 165 to 330 million pigeons (Haag-Wackernagel and Bircher, 2009), with high densities being recorded in cities such as Milan $\left(492 / \mathrm{km}^{2}\right)$ (Sacchi et al., 2002) and Basel $\left(840 / \mathrm{km}^{2}\right.$ ) (HaagWackernagel, 1995).

Resource preferences have been recorded to differ between pigeons inhabiting urban, suburban and rural environments (Krimowa, 2012). While pigeon population densities decrease away from city centres (Sacchi et al., 2002), their densities often exceed socially acceptable standards (Dobeic et al., 2011). Numerous studies (Jones, 2001; Sacchi et al., 2002) suggest that structural design and environmental features of urban areas affect the species' movements, habitat selection and population densities as pigeons make use of infrastructure and anthropogenic resources for life-preserving activities.

Research has indicated a relationship between structural characteristics of buildings and pigeon abundance (Sacchi et al., 2002). Highest densities have been recorded on older buildings (Sacchi et al., 2002) at high altitudes (Shotter, 1978) which resemble the cliffs of their ancestors (Goodwin, 1983), while infrastructure made from glass and reinforced concrete were less favourable due to limited access points (Sacchi et al., 2002). Other factors affecting site selection are the macro and microclimates (Kochert, 1972; Brambilla et al., 2006) thermoregulatory considerations (Bech and Reinertsen, 1989; Körtner and Geiser, 1999), risk of predation (Walsberg and King, 1980; Martin, 1993; Brambilla et al., 2006) and proximity to available resources (Chandler et al., 1995; McCollin, 1998).

By making use of building structures to roost and breed, pigeons select sites that are safe and sheltered (Haag-Wackernagel, 2008) resembling a cave or crevice that their ancestors would have used in rock cliffs (Haag-Wackernagel, 1998). According to Walsberg (1986), energetic costs involved with choosing a site crucially impact the remaining energy available for other life-preserving activities - an idea supported by Haag-Wackernagel and Geigenfeind (2008) who found that pigeons who had identified an ideal site would display special behavioural strategies such as sitting on steeply inclined and narrow ledges or even pass through the smallest of openings $(6 \times 6 \mathrm{~cm})$ to ensure protection from predation and the elements.

Another such activity affecting site selection of buildings is communal roosting. Feral and speckled pigeons have been observed to roost and forage together (Johnston, 1992a; Earle and Little, 1993; Little, 1994; Lofts et al., 1966). Horn (1967) suggests that this behaviour allows pigeons to be more vigilant of predators and improves learnt behaviours relating to foraging success, as individuals are able to follow experienced flock members to abundant and or guaranteed resources. Krimowa (2012) and Johnston and Janiga (1995) found that pigeons roost and or breed in cities but fly to surrounding agricultural areas to feed; while (Earle and Little, 1993) suggest that the opposite is also true whereby pigeons roost in rural areas but fly into the cities to forage. Regardless of seasonal fluctuations in communal roosting (Eiserer, 1984), large pigeon populations making use of urban environments have been considered to reduce the structural integrity of buildings (Krebs, 1974; Hutton and Rostron, 2005; Seamans and Blackwell, 
2011) and are cause for ongoing maintenance and financial outlay (Giunchi et al., 2012).

The University of South Africa's (UNISA) Muckleneuk campus in Pretoria is host to a large number of pigeons. The birds gain access into the buildings through open access points such as loose exterior ceiling boards and open electrical and air conditioning ducts (cabling ducts), positioned on the exterior of the buildings. This easy access increases the number of protected and sheltered breeding and roosting sites available. It has also increased health concerns relating to the build-up of their faeces and associated fungi, nest mites and bird lice which have been reported to infest the offices and inhabitants of certain buildings on campus (Westington, 2013). Faeces and accumulated nesting material build-up on the various external structures of the campus buildings was also a concern raised. According to Ntshoe (2013) large financial inputs have been put towards trying to manage the birds and their associated problems on an ad hoc and reactive basis. University Estates Management, who is responsible for the upkeep of the campus, has identified the need for a long-term and sustainable pigeon control strategy.

The spatial and temporal use of the campus environment by pigeons will therefore be incorporated into an interdisciplinary management plan for a future humane and nonlethal pigeon control strategy for the Muckleneuk campus of the University of South Africa.

This paper explores the overall use of the UNISA Muckleneuk campus by pigeons, by addressing the following objectives and null hypotheses.

\section{Objectives}

- To determine whether pigeon populations fluctuate seasonally on the UNISA Muckleneuk campus

- To confirm the all year round breeding of pigeons on the UNISA Muckleneuk campus

- To determine whether the presence of regional agriculture crop production can be linked with a pigeon population change on the UNISA Muckleneuk campus

\section{Null hypotheses}

- Aspect choice by pigeons on building ledges will not be affected by seasons on the UNISA Muckleneuk campus

- Heights of building levels will not influence ledge use on the UNISA Muckleneuk campus

\section{Materials and Methods}

\section{Study area}

UNISA $(-25.76776,28.199158)$ is situated on top of a hill $(1411.19 \mathrm{~m}$ above sea level) near the central business district of Pretoria in the Gauteng Province of South Africa. The city is surrounded by the Magaliesburg mountain range in the transitional zone between the Central Bushveld and Moist Highveld Grassland vegetation types (Kruger, 2004). The city has a moderate warm temperate climate with an annual minimum and maximum temperature average of $13^{\circ} \mathrm{C}$ (June) and $24^{\circ} \mathrm{C}$ (January) during the course of the study. According to the South African Weather Service (2010) 
precipitation averages $677 \mathrm{~mm}$, while relative humidity ranges between $44 \%$ and $75 \%$ annually. Pretoria experiences 3254 hours of sunshine a year with 2.4 to 2.7 okta cloud cover on average, recorded annually (South African Weather Service, 2010). The Pretoria region within a $20 \mathrm{~km}$ radius of UNISA includes commercial, industrial, suburban and rural areas, with farming and crop (maize, soya, sorghum and sunflowers) production in the surrounding districts (Collett, 2015).

The campus is located within a green belt which includes the surrounding Groenkloof Nature Reserve, Fountains Valley, Apies River, Voortrekker Monument and Freedom Park. Various small mammals and bird species inhabit the University's grounds. These include avian migrants and small raptors (Harris, 2014, pers. obs) (Fig. 1).

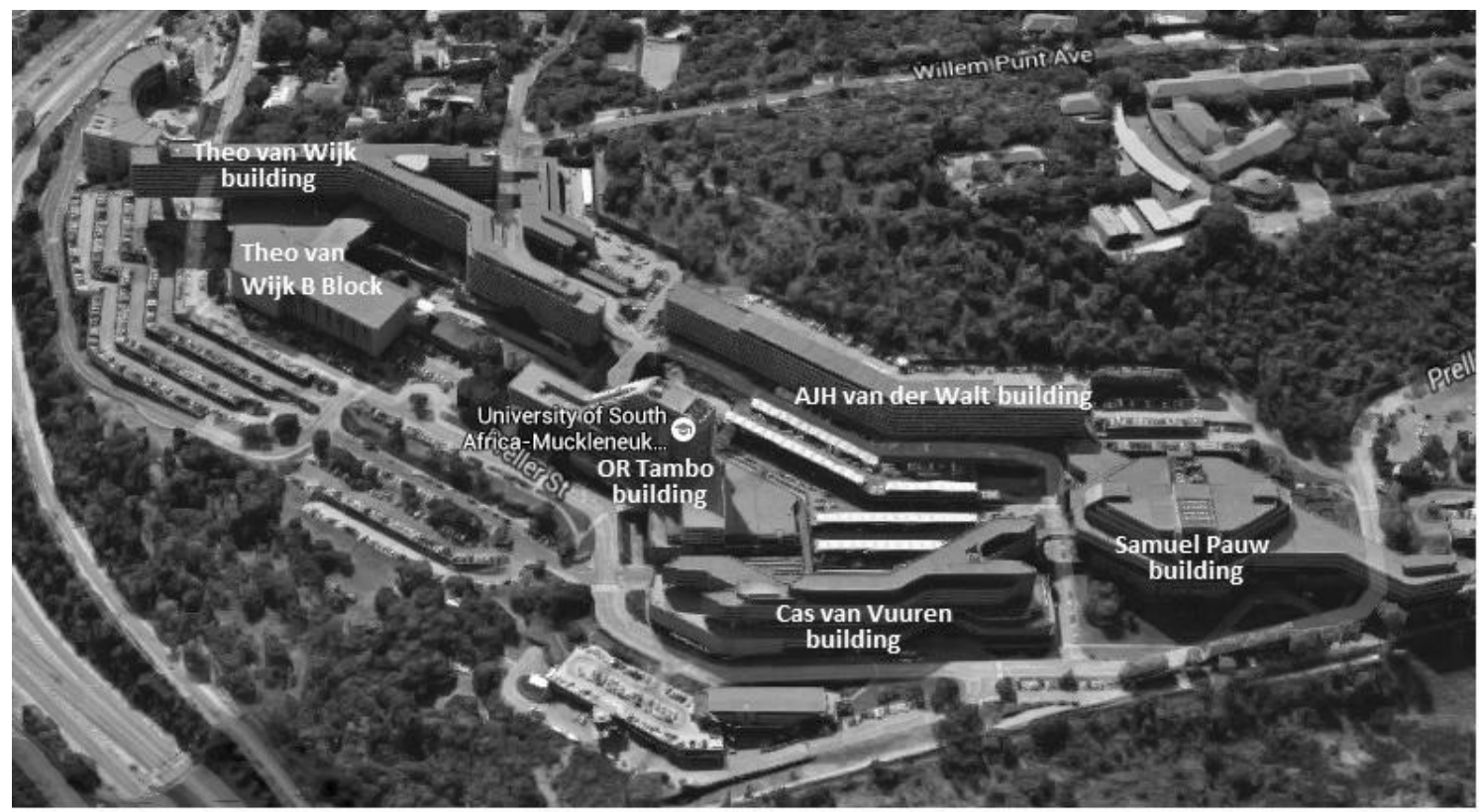

Figure 1. Aerial view of the University of South Africa's Muckleneuk campus indicating the building layout and surrounding habitat where the research took place. The buildings indicated were censused to determine pigeon indices (Google Maps, 2015).

Established in 1972, the Muckleneuk campus consists of seven administrative and academic buildings; however for the purpose of this study five of the seven buildings were investigated as part of the pigeon research. These are as follows: the Theo van Wijk building, OR Tambo building, AJH van der Walt building, Cas van Vuuren building and Samuel Pauw building (Fig. 2). Each building is unique in its design, providing various roosting and nesting site possibilities for the pigeon population on the campus. Academic and administrative offices positioned lengthwise along the buildings face out onto balconies.

Theo van Wijk, the largest building positioned on the far western side of the campus, has 11 levels uniform in design with balconies and exterior cabling ducts running the length of the building. Due to its y-shape, the building offers two north facing and two south facing aspects. The Philadelphia cafeteria is positioned on the third floor, which includes an extensive catering balcony. 


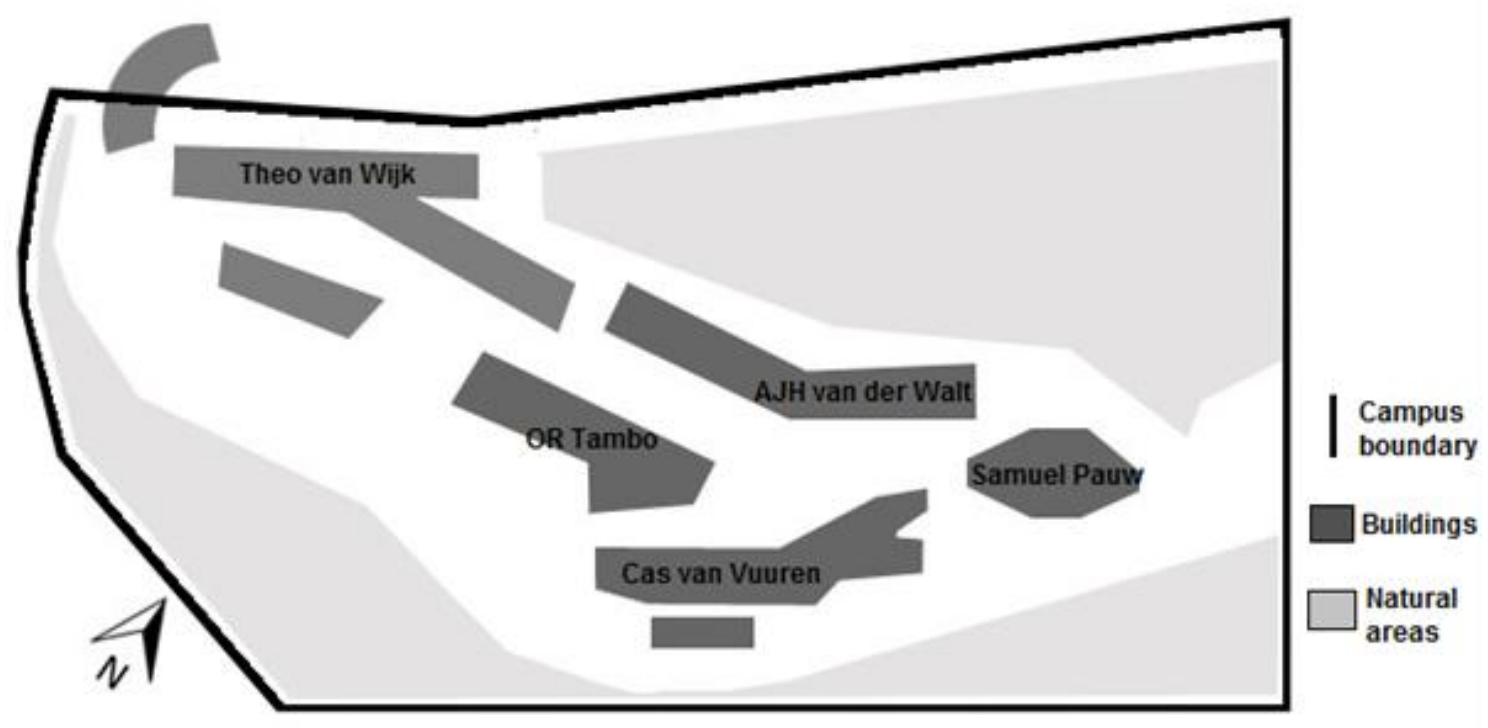

Figure 2. The University of South Africa's Muckleneuk campus in Pretoria, indicating the five buildings used in the pigeon count, showing their proximity to each other and indicating north

The AJH van der Walt building is positioned on the northern side of the campus facing an undeveloped vegetated mound which meets the campus' northern boundary. All seven levels are continuous in balcony and cabling ducts design.

To the east of the campus is the library, the Samuel Pauw building, roughly hexagonal in shape with eight levels; it has continual cabling ducts and balconies. Beyond this building towards the campus boundary in the east is parking space and natural vegetation.

OR Tambo, the administrative building, is positioned to the south. Due to its 14 levels, it is the tallest building on campus. Balconies and cabling ducts provide uniform exterior structural design, with the exception of the Good Hope cafeteria and balcony positioned on level four.

Adjacent to the OR Tambo building is Cas van Vuuren with seven levels. It is the only structural exception, as no exterior cabling ducts is positioned above its balconies. Natural areas extend to the southern and south western boundaries.

A characteristic of all the buildings are the loose, broken or open exterior ceiling boards and or cabling ducts can be found on all the buildings which provide additional roosting and breeding space for the pigeon population on campus.

\section{Objective 1}

Data was collected for a full year from the beginning of March 2013 to the end of February 2014. The counting of adult and juvenile pigeons took place during the pigeons' bimodal foraging activity periods, which have been recorded to peak in the morning and afternoon (Krebs, 1974; Rose et al., 2006; Soldatini et al., 2006). These counts took place early morning during the first two hours after sunrise and again in the evening during the last two hours before sunset, once a week for 52 weeks. If the particular chosen day for counting experienced extreme weather conditions, then the next consecutive day with fine weather was chosen and documented. 
The observer maintained a standard designated route in a west to east direction, counting each of the campus' five buildings during the course of the research period. Observations were aided binoculars, digital camera and dictaphone, later transcribed onto data sheets. Double counts of individuals taking off and perching on the same building was taken into consideration and avoided. As the pigeons were wild and free roaming, the exact number of pigeons on campus could not be determined. An increase or decrease in the number of pigeons counted was in essence a reflection of an increase or decrease in pigeon presence. Presence was represented as an index to monitor the extent of the increases or decreases as actual numbers could not be attained through the methodology implemented. The paper will therefore refer to indices to convey the extent of the pigeon presence, and it changes over time.

The objective to determine whether pigeon populations fluctuate seasonally on the UNISA Muckleneuk campus required the arithmetic mean and standard errors of the monthly pigeon population indices to be depicted graphically for both the Speckled and Feral pigeons over the course of a full year. The graphical representation of the data will be described and inferences will be supported by literature reviews on pigeon ecology and the seasonal parameters of the study area.

\section{Objective 2}

Breeding season fluctuations have been debated extensively over the years (Lofts et al., 1966; Shotter, 1978; Shetty, 1992; Hetmański, 2004; Rose et al., 2006). The objective was to determine whether breeding on the campus's buildings took place all year round or indeed fluctuated seasonally. This was determined by observing breeding activity through reproductive behaviour, nesting behaviour (Shotter, 1978) and or the presence of young pigeons. The following reproductive associated behaviours were recorded: courting, mating, nesting, squab presence and juvenile presence. Courting referred to vocalisations and head bobbing of a male pigeon directed at a female pigeon. Mating referred to copulation of a male pigeon mounted onto the back of a female pigeon. Nesting referred to activities associated with active nest building or physically sitting on nests. Squabs describes very young pigeons in nests from the date of hatching to one month old when they are due to fledge from the nest (Krebs, 1974; Hetmański and Wołk, 2005). Juveniles describe young pigeons (one to six months of age) which have fledged the nest but have not yet obtained adult plumage (Murton et al., 1972a; Murton et al., 1972b).

If breeding were to be taking place all year round, the assumption would be that all breeding activity and reproductive behaviours would in fact be present all year round with no significant peaks being associated with seasonality. The presence or absence of a breeding activity or a reproductive behaviour was recorded during each count. Data was then converted from 52 (week) counts to 12 (month) counts. The presence or absence could now be ranked, where 0 referred to no presence of a breeding activity and or reproductive behaviour within a particular month, to 4 referring to a particular activity or behaviour as having been present in each of the 4 weeks of that particular month.

\section{Objective 3}

In order to identify a relationship between surrounding agricultural crop production and the pigeon population index fluctuation on campus, a list of agricultural crops 
ecologically important to pigeons (maize, sorghum and sunflowers) within a 20 kilometre radius of the Muckleneuk campus, was obtained from the Department of Agriculture, Forestry and Fisheries. Twenty kilometres is the distance from an urban centre that is considered to experience the highest agricultural damage by pigeons (Earle and Little, 1993; Little, 1994; van Niekerk, 2009). Their respective planting and harvesting times were linked to the pigeon population index on campus. While no statistical methodologies were applied to this data, inferences were made with regards agricultural crop use by the pigeons and associated with their presence on the campus during these times. These inferences were supported by literature reviews on pigeon foraging behaviours through a process of deductive reasoning.

\section{Hypothesis 1}

To determine whether building aspect and or height influenced the use of buildings by pigeons, OR Tambo (14 levels, $46.2 \mathrm{~m}$ ), the campus' tallest building was used. Data on the number of pigeons perched out in the open on balcony ledges and or cabling ducts was recorded in relation to height and aspect. Counts were conducted on the north and south side between levels four and fourteen, as these were identical in structural design. The roof was also counted, but for the purpose of data analysis, was not included, as it was not identical in structure to the other levels.

The first null hypothesis stated that aspect choice by pigeons on building ledges will not be affected by seasonality. As such, a chi-square test, typically used to compare observed data with expected data was used to determine if there was in fact a significant association between the north and south sides of the OR Tambo building, for each of the four seasons.

\section{Hypothesis 2}

The second null hypothesis states that the heights of the building levels will not influence ledge use by the pigeons. A Spearman's rho correlation does not assume any assumptions about the distribution of data and is considered an appropriate correlation analysis for variables in an ordinal scale. The building levels were therefore ranked to levels according to height and the Spearman's rho correlation determined whether or not an association between the height of the building and pigeon use / presence exists. This was also done for each season respectively.

Institutional ethical clearance and permission (2013/CAES/017) was received for the research.

\section{Results}

\section{Objective 1}

The pigeon population index on the Muckleneuk campus had an arithmetic mean value of 344 individuals/month over the course of the year $(\mathrm{SE}=10)$. Speckled pigeons constituted the majority of the pigeons on campus at $84 \%(\overline{\mathrm{x}}=290$ individuals/month; $\mathrm{SE}=8)$ and feral pigeons considerably less at $16 \%(\overline{\mathrm{x}}=55$ individuals/month; $\mathrm{SE}=4)$ of the total pigeon population (Fig. 3). 


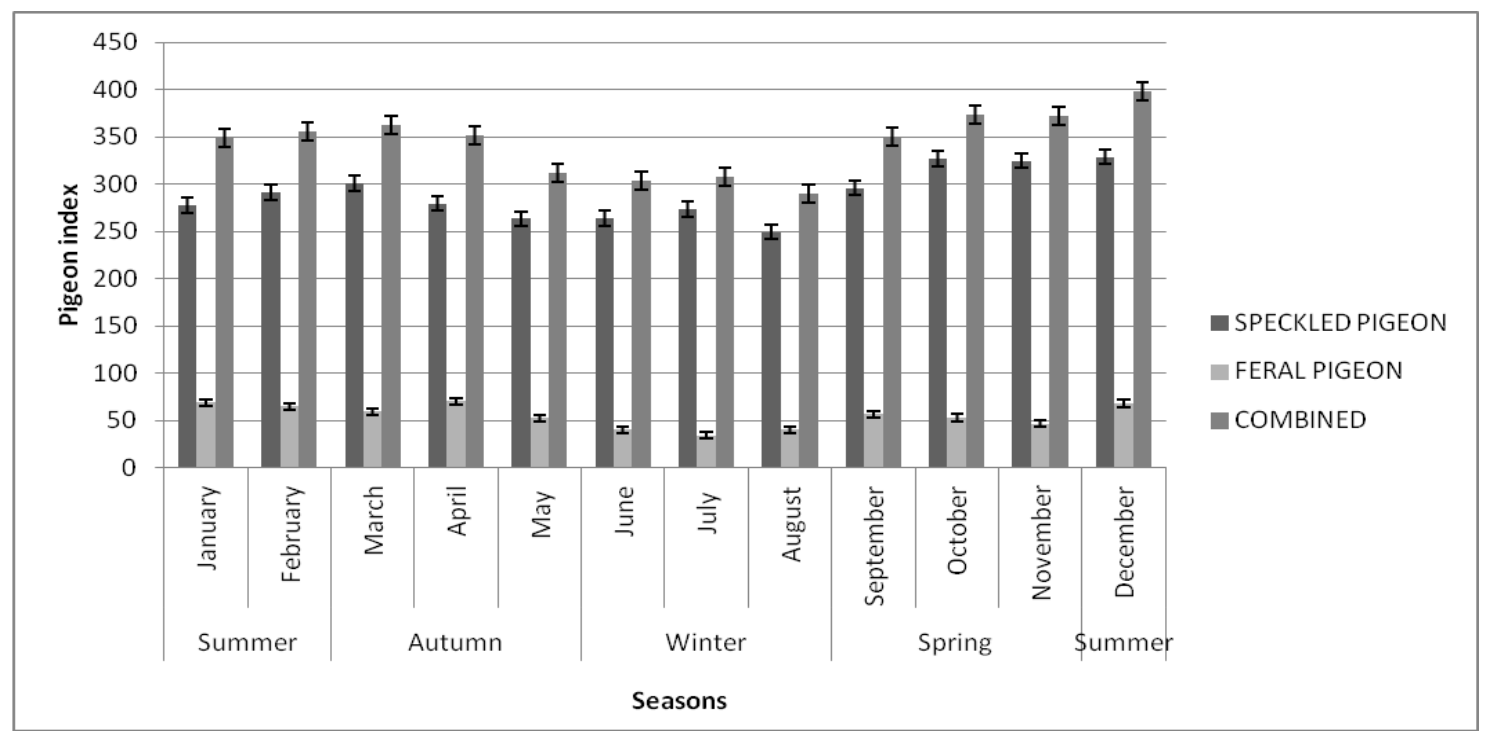

Figure 3. Indicating the pigeon population indices for both Speckled and Feral pigeon populations on the UNISA Muckleneuk campus from March 2013 to February 2014

It was found that the pigeon populations on the UNISA Muckleneuk campus does fluctuate seasonally as population indices for both speckled and feral pigeons peaked during the spring $(\overline{\mathrm{x}}=365 ; \mathrm{SE}=4)$ and summer $(\overline{\mathrm{x}}=367 ; \mathrm{SE}=8)$ seasons and similarly declined during autumn $(\overline{\mathrm{x}}=342 ; \mathrm{SE}=8)$ and winter $(\overline{\mathrm{x}}=300 ; \mathrm{SE}=3)$ seasons.

\section{Objective 2}

The presence of breeding activity on campus was evident throughout the year (Table 1).

Table 1. Presence of breeding activity and reproductive behaviour of the Muckleneuk campus pigeon population in ascending order of rank

\begin{tabular}{|l|l|c|c|c|c|c|}
\hline \multicolumn{7}{|c|}{ PRESENCE OF NESTING BEHAVIOUR } \\
\hline SEASONS & MONTHS & COURTING & MATING & NEST & SQUAB & JUVENILE \\
\hline \multirow{3}{*}{ Summer } & January & 0 & 1 & 2 & 2 & 2 \\
\cline { 2 - 7 } & February & 2 & 2 & 1 & 3 & 0 \\
\hline \multirow{3}{*}{ Autumn } & March & 0 & 0 & 0 & 2 & 0 \\
\cline { 2 - 7 } & April & 0 & 0 & 0 & 1 & 1 \\
\cline { 2 - 8 } & May & 0 & 1 & 1 & 2 & 0 \\
\hline \multirow{3}{*}{ Winter } & June & 0 & 1 & 1 & 3 & 0 \\
\cline { 2 - 8 } & July & 0 & 2 & 2 & 3 & 0 \\
\cline { 2 - 8 } & August & 0 & 1 & 2 & 4 & 0 \\
\hline \multirow{3}{*}{ Spring } & September & 0 & 0 & 1 & 1 & 0 \\
\cline { 2 - 8 } & October & 1 & 1 & 0 & 2 & 3 \\
\cline { 2 - 7 } & November & 0 & 0 & 0 & 0 & 2 \\
\hline
\end{tabular}


However, a marked decrease in activity presence relating to reproductive and nesting behaviour was documented in autumn. There was an increase in squab presence during the winter and spring months coinciding with the annual peak breeding season (July to October). Low juvenile presence was noted during the year.

\section{Objective 3}

The speckled pigeon population index showed an increase between January to April $(\overline{\mathrm{x}}=287 ; \mathrm{SE}=3)$ and again in September to December $(\overline{\mathrm{x}}=319 ; \mathrm{SE}=4)$. The objective that agricultural crop production will correlate with pigeon population change was therefore found to be true. Feral pigeons supplement their diet with dry maize and sunflower seeds during harvesting in the autumn/winter months (May to August) (van Niekerk, 2003). However, their population index declined $(\overline{\mathrm{x}}=42 ; \mathrm{SE}=2)$ in relation to the rest of the year $(\overline{\mathrm{x}}=61 ; \mathrm{SE}=2)$ when crop seed availability is instead exploited by speckled pigeons - this decrease coincides with the colder winter months (Fig. 4).

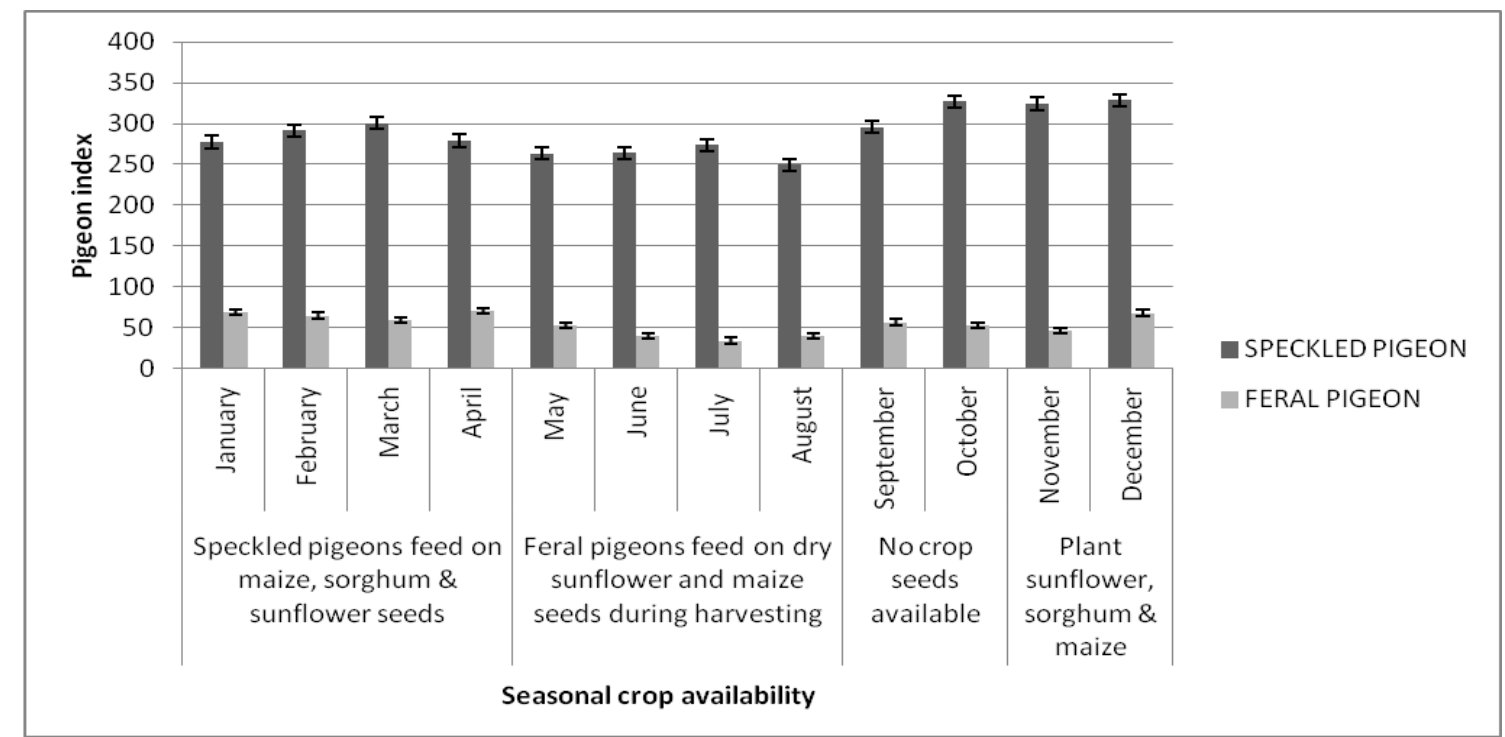

Figure 4. Pigeon population indices for both Speckled and Feral pigeons on the UNISA Muckleneuk campus from March 2013 to February 2014, and indicating the seasonal availability of crops within a $20 \mathrm{~km}$ radius of the study site

\section{Hypothesis 1}

The selection and use of sites by pigeons aid survival and reproduction of the species. The null hypothesis stating that the choice of a building's aspect will not be affected by season was rejected, as significant differences were observed in all the seasons except winter $\left(X^{2}(\mathrm{df}=1, \mathrm{n}=52)=0.26, \mathrm{p}=0.610\right)$ as indicated in Table 2. These results are graphically illustrated in Fig. 5. 
Table 2. Seasonal difference in balcony ledge use by pigeons on the north and south side of the OR Tambo building

\begin{tabular}{|l|r|r|r|r|}
\hline & \multicolumn{1}{|c|}{ Summer } & \multicolumn{1}{c|}{ Autumn } & \multicolumn{1}{c|}{ Winter } & \multicolumn{1}{c|}{ Spring } \\
\hline *Chi Square statistic & 6.02 & 16.95 & 0.26 & 4.14 \\
\hline Df & 1 & 1 & 1 & 1 \\
\hline *P-value & 0.014 & $<0.0001$ & 0.6101 & 0.0419 \\
\hline
\end{tabular}

$*$ [Note that for $\mathrm{df}=1$, the calculated value of chi-square is corrected for continuity.]

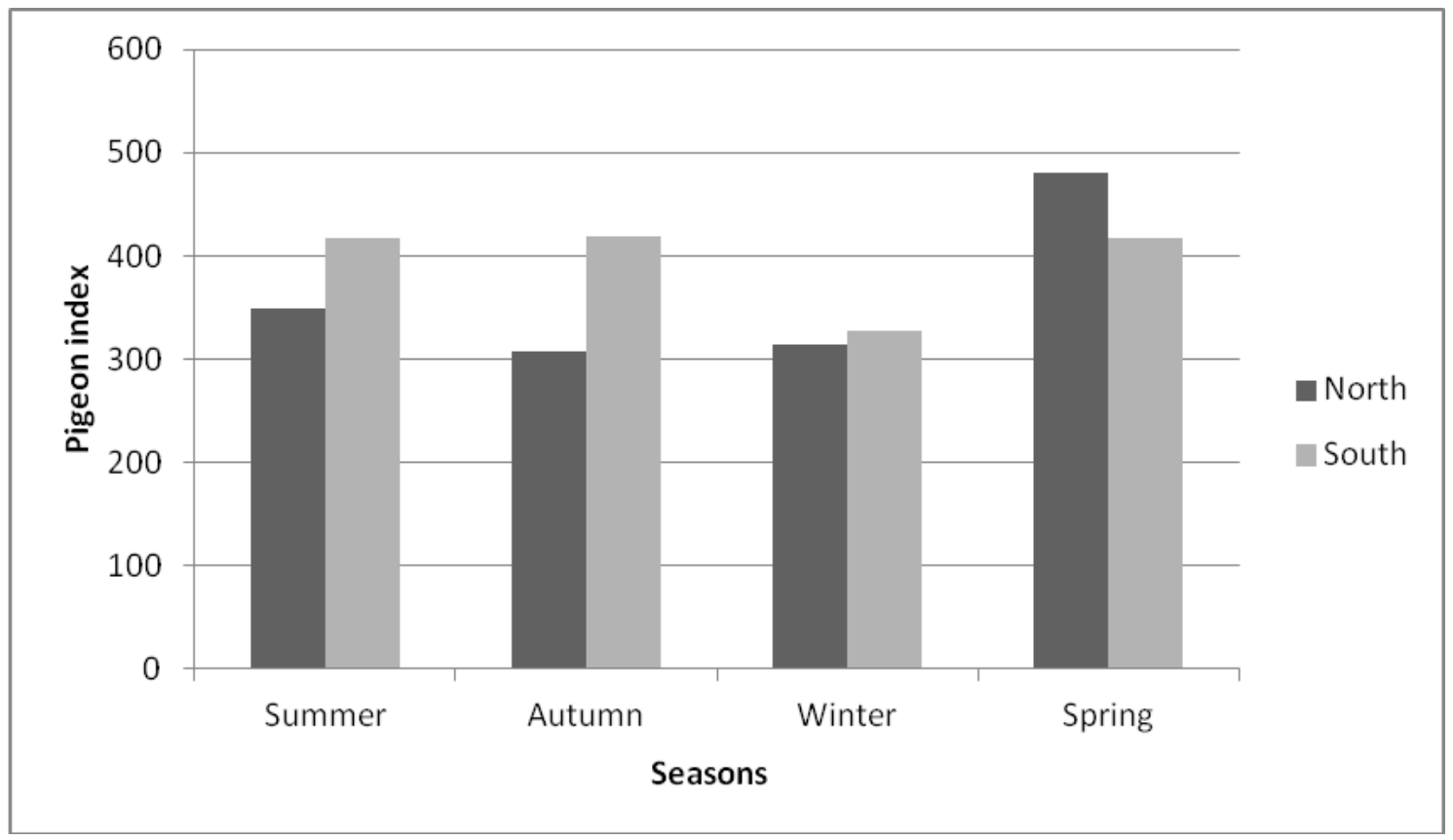

Figure 5. Indicating the seasonal aspect choice by both Feral and Speckled pigeons collectively on the OR Tambo building of the UNISA Muckleneuk campus from March 2013 to February 2014.

\section{Hypothesis 2}

Pigeons perching on the cabling ducts and balcony ledges of the OR Tambo building, the tallest building with 14 levels (46.2 metres), indicated a preference in the choice of level. The study rejected the null hypothesis of no association between the height of building levels and ledge use, as Spearman coefficients indicated a positive significant relationship, and a moderately strong association between the number of pigeons on the building ledges and the building level $\left(\mathrm{r}_{\mathrm{s}}=0.64, \mathrm{p}=0.035\right)$ (Table 3). For the purpose of analysis the number of pigeons making use of the roof (level 15) was not included as the structure is not identical to the other ledges - as indicated in Fig. 6. 
Table 3. Correlation between number of perched pigeons and level height on OR Tambo building

\begin{tabular}{|c|c|c|c|c|}
\hline \multirow{6}{*}{$\begin{array}{l}\text { Spearman's } \\
\text { rho }\end{array}$} & \multirow{3}{*}{ Level } & $\begin{array}{l}\text { Correlation } \\
\text { Coefficient }\end{array}$ & 1.000 & $.636^{*}$ \\
\hline & & Sig. (2-tailed) & & .035 \\
\hline & & $\mathrm{N}$ & 11 & 11 \\
\hline & \multirow{3}{*}{ Count } & $\begin{array}{l}\text { Correlation } \\
\text { Coefficient }\end{array}$ & $.636^{*}$ & 1.000 \\
\hline & & Sig. (2-tailed) & .035 & \\
\hline & & $\mathrm{N}$ & 11 & 11 \\
\hline
\end{tabular}

*Correlation is significant at the 0.05 level (2-tailed).

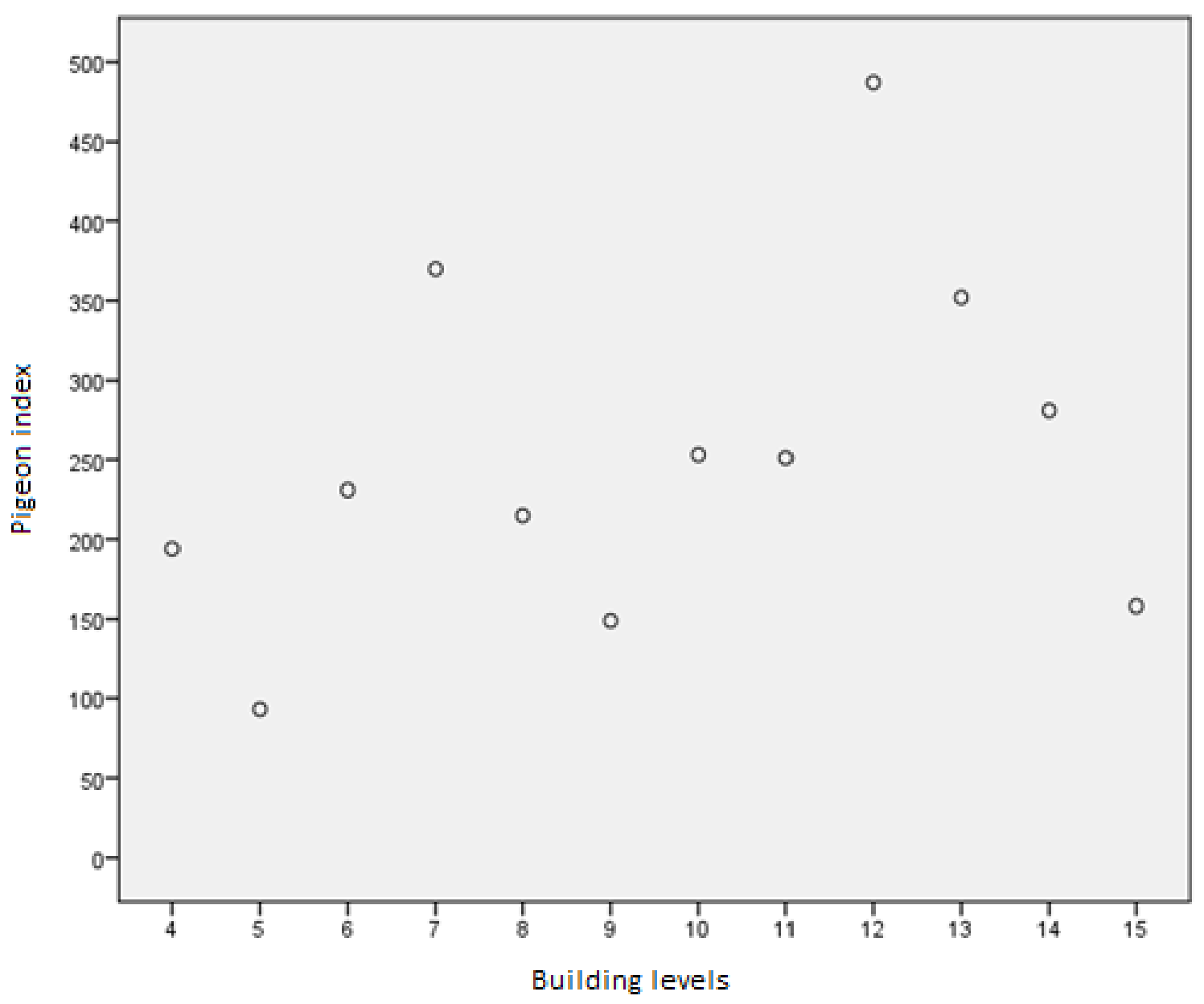

Figure 6. A scatter plot indicating the correlation between pigeon indices and ledge height selection, on the OR Tambo building on the UNISA Muckleneuk campus from March 2013 to February 2014

\section{Discussion}

\section{Pigeon ecology}

Speckled and feral pigeon populations indices on the University's Muckleneuk campus indicated a small yet distinct seasonal fluctuation. The study found that the 
pigeon population index peaked in spring $(\overline{\mathrm{x}}=365)$ and summer $(\overline{\mathrm{x}}=367)$ and declined during autumn $(\overline{\mathrm{x}}=342)$ and winter $(\overline{\mathrm{x}}=300)$ similar to the outcome of numerous studies (Hetmański and Wołk, 2005; Giunchi et al., 2012; Murton et al., 1972b). Ecological factors (Ali et al., 2013) such as breeding activity, seasonal variations, resource distribution and availability (Soldatini et al., 2006), regulates the seasonal patterns of pigeons in urban environments. Increased visibility of pigeons perched on building ledges during the warmer months contributed to the population index peaks noted during spring and summer with minimum and maximum temperature averages ranging between $15^{\circ} \mathrm{C}-28^{\circ} \mathrm{C}$ (ICAE, 2013). Whilst in winter, when the average minimum and maximum temperatures in Pretoria range between $6^{\circ} \mathrm{C}-23^{\circ} \mathrm{C}$ (ICAE, 2013), the pigeons were most likely hidden from the cooler elements and consequentially also from the observer.

This finding is similar to findings of European studies which describe pigeon population increases during breeding season and declines in winter (Johnston and Janiga, 1995; O'Regan et al., 2012). However, this finding is in contrast to a study conducted in the coastal city of Wellington, New Zealand, which found that pigeon population densities were higher in winter (6.8/ha) as individuals were more visible during courting or in search of mates, in comparison to the summer months $(4.5 / \mathrm{ha})$ when they were less detectable because of nest incubation (Ryan, 2011).

That said the population structure on the Muckleneuk campus remains stable and relatively constant regardless of the rise and fall between the warmer and cooler months leading to the deduction that it is in fact a resident population utilising the permanent resources available. This was corroborated by Ali et al. (2013), who found that the pigeon population density in Pakistan remained relatively similar over the seasons due to constant roosting and nesting sites and food and water availability, all of which can be found on the Muckleneuk campus.

Resource abundance results in the extension of the breeding seasons (Shochat et al., 2010) and improved reproductive capacities (Ryan, 2011). Pigeons are physiologically ready to start breeding between six to seven months of age (Murton et al., 1972a; Murton et al., 1972b). Once a mate is found, they pair for life (Johnston, 1992b) producing up to 12 squabs a year (Mooallem, 2006; Haag-Wackernagel, 2008), if the pair is experienced in overlapping clutches, to shorten clutch intervals (Krebs, 1974; Hetmański and Wołk, 2005). The research found that breeding seasons did not affect the pigeon population's use of the Muckleneuk campus, as the presence of breeding activity was recorded all year without seasonality. This finding is supported by numerous studies which found that pigeons breed throughout year, the extent of which depends on food availability and climate (Lofts et al., 1966; Hetmański and Wołk, 2005; Hutton and Rostron, 2005; Ryan, 2011; Murton et al., 1972b). Shotter (1978) and Mooallem (1969) also found this to be true for studies of pigeons in Africa where breeding activity occurred year-round with a peak between July to October. Shetty (1992) explain how pigeons are non-seasonal breeders. However, just because pigeons are physiologically capable of prolonged breeding, it does not necessarily mean that they do (Lofts et al., 1966). Murton et al. (1972b) explain that not all pigeons in a population breed simultaneously, or even throughout the year - meaning that some pigeons breed erratically or not at all. This could be the reason for the low presence of reproductive and nesting behaviour noted in November, or a direct response to the regular weekly sightings of pied crow (Corvus albus), a known predator of pigeons (Gregory and Marchant, 1995; Gorrski, 1997; Wanless and Jupiter, 2002), over the buildings 
throughout the month (Harris, 2014, pers. obs.), resulting in pigeons being less detectable as they cower in roosts or on nests (Hutton and Rostron, 2005; Hutton and Dobson, 1993).

Numerous factors affect the breeding of pigeons. Hetmański (2004) suggests these factors to be historical as ancestral breeding seasons were prolonged, intra-populational as some individuals are more experienced in breeding and therefore able to frequently overlap clutches for maximum reproductive output, and extrinsic in terms of food availability and seasonal day length. The latter affects physiological functions as photoperiods act as a timing device for gonadal regression in anticipation of moulting during autumn. This was evident on the Muckleneuk campus, where the presence of courting, mating and nesting activities were not recorded between March to April. This drop in breeding activity allows costly energy to be diverted for feather regrowth and plumage change (Murton, 1966; Johnston and Janiga, 1995). Lofts et al. (1966) did however find that not all pigeons in a population go through this regression and do not therefore remain in a reproductive condition for continual breeding.

The rearing process of squabs from hatchling to fledgling takes between four to six weeks (Krebs, 1974; Jacquin et al., 2010). On fledging the nest, juveniles undergo natural dispersion towards lower density populations, thereby allowing the parent population to remain stable (Hetmański, 2007). The low presence of juveniles on the University's campus may be indicative of the $30 \%$ of fledglings that disperse yearly (Hetmański, 2007). These results paralleled Skead's (1969) observations who noted the relative absence of juveniles in speckled pigeon flocks even though breeding occurred throughout the year.

Food availability and distribution is another extrinsic factor which affects breeding and therefore population density and structure. Flocks living within urban environments have adopted flexi foraging strategies to maximise on food consumption (Rose et al., 2006), in addition to retaining the foraging habits of their ancestors who utilised agricultural fields as their primary source of food [Goodwin, 1983; Little, 1994; Ryan, 2011).

Pigeon populations worldwide have been recorded to commute from urban roosts to farmlands and agricultural feeding grounds, often in very high numbers (over 6500 pigeons in Pisa (Giunchi et al., 2012), and in doing so create very large temporary congregations - over 5000 pigeons in Gauteng (van Niekerk, 2003).

Pigeons in South Africa feed extensively on sunflower seeds, maize and sorghum (van Niekerk, 2003; van Niekerk and van Ginkel, 2004), often travelling 3 to 50 kilometres daily to feed on these crops (van Niekerk, 2009). Studies have shown that the highest degree of damage to crops by pigeons is within 20 kilometres of a city (Earle and Little, 1993; Little, 1994; van Niekerk, 2009). Within a 20km radius of the campus nearly a total of 130 maize, sunflower and sorghum fields were available to pigeons for consumption before and during the harvesting season when speckled and feral pigeons show preference for moist and dry seeds (van Niekerk and van Ginkel, 2004; Collett, 2015).

Pigeons display bimodal feeding because of the alternation of sexes on the nest (Johnston and Janiga, 1995; Krimowa, 2012). Rose et al. (2006) found that the females incubate through the night and early morning and are only relieved once the males return from their morning foraging; thereafter the females leave to forage until the afternoon, thus resulting in at least one individual of a pigeon pair remaining on campus at any given time. Crop availability for speckled pigeon falls in the months just prior to 
ripening of maize, sorghum and sunflower seeds in January to April, with limited crop seeds being available for consumption between September and December when planting recommences (van Niekerk, 2003; van Niekerk and van Ginkel, 2004). During the preharvest months (January to April) speckled pigeons have been recorded to feed on the moist crop seeds, thought to sustain energy and endurance for long distance flights (van Niekerk, 2003). The slight percentage difference between the two spring/summer peaks in the Muckleneuk campus population index may be inversely related to crop availability, thus supporting the objective that agriculture crop production will correspond with pigeon population change. During the available crop seed months individuals may have departed at first light to maximise on food availability in farmlands as suggested by Counsilman (1974), leaving their partners to incubate on nests. In doing so fewer pigeons were visible on the buildings. The higher speckled pigeon population density index during the months when crops were less likely to provide guaranteed sustenance (September to December) may be related to energy expenditure (Bryant, 1997). Pigeons may be aware of the lower agricultural availability, and therefore do not waste costly energy undertaking long distance flights towards the farmlands when they are required to forage locally, thus remaining on buildings for longer periods.

Feral pigeons rely heavily on deliberate feeding and scraps (Brown, 1969; Little, 1994), with dry maize kernels available during harvesting (May to August) to a lesser extent (Soldatini et al., 2006). Of the resident pigeon population on campus, feral pigeons constitute $16 \%$. These individuals may make use of the campus for roosting and breeding whilst exclusively travelling to surrounding maize fields. This is, however, unlikely considering the anthropogenic food availability on campus around which they congregate (Harris, 2014, pers. obs.).

\section{Site selection ecology}

Pigeons have been recorded to favour certain heights when making use of natural and man-made sites (Haag-Wackernagel and Geigenfeind, 2008). Pigeons making use of ledges on the north and south facing sides of the OR Tambo building indicated a preference for the southern aspect during autumn $\left(X^{2}(\mathrm{df}=1, \mathrm{n}=52)=16.95, \mathrm{p}<\right.$ $0.0001)$ and summer $\left(X^{2}(\mathrm{df}=1, \mathrm{n}=52)=6.02, \mathrm{p}=0.014\right)$, contrary to numerous avian studies which documented a northerly site selection (Leonard, 1998; Körtner and Geiser, 1999; Ontiveros, 1999; Fisher et al., 2004). Studies demonstrate that the primary motivation for a northerly aspect preference is energetic considerations (Walsberg, 1986; Zwartjies and Nordell, 1998; Antczak, 2010). Yet during the coldest season, when the warmer northerly side would minimise heat loss and thermoregulation costs, pigeons did not indicate a significant preference $\left.X^{2}(\mathrm{df}=1, \mathrm{n}=52)=0.26, \mathrm{p}=0.610\right)$.

Winter climate in Pretoria is cool and dry with the annual rainfall of approximately $700 \mathrm{~mm}$ being experienced during the summer months (ICAE, 2013). Climatic temperatures in Pretoria rarely drop below zero as average temperatures range between $6^{\circ} \mathrm{C}-23^{\circ} \mathrm{C}$, therefore the need to warm up quickly after a cold night is not as acute as in the Northern Hemisphere where a northerly site with higher temperatures would be beneficial to survival. Maximum sun exposure during winter, heat retention of building materials, insulated balconies and cabling ducts availability create warmer microclimates and minimise exposure to low temperatures. Thus the selection of sites is not influenced by cold climatic conditions. 
Aspect choice may also be environmentally related, as sites are chosen in relation to the direction of preferred feeding sites (Chandler et al., 1995; Sacchi et al., 2002). Pigeons indicated a significant preference for the southern aspect when seasonal crop availability was at its highest. Maize, sorghum and sunflower seeds are planted and ripen during summer and autumn thus correlating with a peak in pigeon foraging. The nature reserves and protected areas located to the south of the campus also have natural grasses which flower and produce seed which are consumed by pigeons, within the overlapping summer and autumn months. Due to the campus positioning, flocks in excess of 40 speckled pigeons were recorded departing from the campus and flying in a south-easterly direction during the early mornings in summer to forage in surrounding agricultural lands. The converse applied in spring, when pigeons indicated a northerly site selection preference as preferred foraging sites had limited crop availability.

The height at which sites are selected also affects ecological parameters. Having originally descended from the coastal and inland cliffs (Goodwin, 1983), pigeons have easily adapted to prominent tall buildings in urban environments (Hutton and Rostron, 2005). The pigeon population on the ledges of OR Tambo building indicated a positive significant relationship with a moderately strong association between the number of pigeons using the ledges and the building level $\left(r_{s}=0.64, p=0.035\right)$. Pigeons and level indicated an upward trend, with the pigeon index increasing in ledge use the higher the level. These results are supported by a nesting ecology study which found band-tailed pigeons (Columba fasciata) nesting at heights of 26.5 and $36.3 \mathrm{~m}$ depending on the natural substrate (Leonard, 1998). Similarly, in human-modified habitats, Shotter (1978) found that pigeons on the Ahmadu Bello University campus in Nigeria preferred ledges at high altitudes while (Haag-Wackernagel, 2008) recorded pigeon sites to be positioned at elevated altitudes and on the upper sections of structures.

Preference for elevated heights is considered to contribute to the creation of microclimates, in particular thermoregulation, as high altitudes allow for individuals to control insulation by reducing the exposure to cold temperatures (Mosher and White, 1976). Site placement can also offer updrafts which aid in flight (Kochert, 1972). High positioning of sites essentially contribute to the evasion of predators as height, along with sheltered building features offer protection and camouflage (Körtner and Geiser, 1999). However, the opposite is true for pigeons that make use of the roof without the protective structural characteristics found on the other levels. Previously considered to be 'safe-zones' due to lower predator pressure (Jokimäki et al., 2005) urban areas no longer hold this characteristic as several raptor species have adapted to the modified macro-climate of cities which provide suitable nesting sites and an abundance of prey species (Ratcliffe, 1993). The exposure of pigeons to the elements, but more importantly to predators, is the driving factor which limits the selection of sites on the roof of buildings. This is especially applicable as pied crows (Corvus albus), peregrine falcons (Falco peregrinus) and African goshawks (Accipter tachiro), known predators of pigeons, have been identified on campus (Harris, 2014, pers. obs.).

\section{Conclusion}

Pigeons over the centuries have become one of the most successful colonisers of urban environments (Haag-Wackernagel et al., 2006). They developed the remarkable ability to utilise buildings to nest, breed and roost while simultaneously exploiting various forms of food supplied by urban lifestyles and surrounding farmlands. The 
pigeon population on UNISA's Muckleneuk campus is no different. The population index indicated peaks over the warmer months, and a decline during the cooler periods. The population has however been considered to be stable and constant, regardless of fluctuations as the difference between peaks and dips is nominal along with suggested juvenile dispersal.

Responses to environmental releasers (day length), proximity of available food and known predators were evident in the population. Pigeons considered energy drivers with regards to foraging, as the population index was higher on campus when crops were not at their optimum for consumption, and lower when crop seeds were available as they departed early to maximise on consumption on neighbouring agricultural fields.

Unlike most avian studies relating to spatial dynamics, the University's pigeon population on the OR Tambo building indicated significant differences between the north and south aspect in all the seasons except for winter. Temperate climate and feeding site direction during optimal agricultural availability contributed to the behavioural responses and energetic decisions of pigeons when choosing sites in relation to aspect. The investigation of pigeons making use of OR Tambo building in relation to aspect and height was limited to individuals on the balcony ledges and cabling ducts. However, this is not a true representation of the selection of roosting and nesting sites as those on the floor of the balcony, in cabling ducts or in open access points, were not visible and thus not recorded. A further study of actual nesting and roosting sites needs to establish preference for aspect and building height in relation to breeding and roosting sites.

Pigeons did however support other research study findings with regards to site selection and building height. Individuals chose the higher altitudes on which to select their sites, as the benefits of controlled microclimates and predator evasion contribute to their survival.

Pigeons are known to display nest and roosting site plasticity (Haag-Wackernagel and Geigenfeind, 2008) while architectural features, age and substrate colour of buildings have been recorded to affect site selection (Sacchi et al., 2002; Ali et al., 2013). The University's Muckleneuk campus' building design and structure dates back over forty years reflecting prominent architectural overhangs, ledges and balconies which provide ideal environments for roosting and breeding pigeons. Human negligence is also a contributing factor as exterior ceiling boards and cabling ducts are left open providing safe and sheltered access to pigeons. Only one of the buildings in the study did not have cabling ducts which in turn provides fewer sites for pigeons to breed and roost in comparison to the remaining six buildings. Due to the inconsistency in the design and size of each of the buildings, comparative data could not be collected and therefore the difference in pigeon preference could not be established. Nonetheless, it can be suggested that due to the favourable benefits obtained from roosting and breeding in abundant open cabling ducts, accessible balcony ceilings and structural overhangs, pigeons are able to breed without restricted safety and spatial limitations.

The use of urban environments within space and time by wildlife has been a topic of discussion by researchers for many years (Philo and Wilbert, 2000). There is a need to understand the implications of man-made developments, urban-related consequences and opportunities on urban wildlife inhabiting these spaces in order to understand how they use these fragmented environments. An idea seconded by Ditchkoff et al. (2006), considers science to be lacking in understanding wildlife management in urban spaces, thus resulting in continual challenges and difficulties in managing these wildlife 
populations. Hutton and Rostron (2005) also stated that inappropriate strategies to control populations often result from wildlife management programmes when management and building professionals have a lack of understanding the problem.

Knowledge of pigeon biology, ecology and behaviour relating to the use of urban environments are therefore important factors to consider when designing wildlife management plans (Giunchi et al., 2007; Giunchi et al., 2012). Cities need to be recognised as ecosystems, with new niche habitats that require specific attention and management, ultimately guided by wildlife's use of urban spaces.

Pigeon population fluctuation will be used as a control to determine the efficiency of various humane and non-lethal control measures implemented on the campus. The combined results will inform an interdisciplinary management plan for pigeon control on the University of South Africa's Muckleneuk campus.

Acknowledgements. Acknowledgement and thanks to the University Estates Department, the Applied Behavioural Ecological and Ecosystem Research Unit (ABEERU) at the University of South Africa and the National Research Foundation (NRF) for funding. Climatic and agricultural data was provided by the South African Weather Service and the Department of Agriculture, Forestry and Fisheries.

\section{REFERENCES}

[1] Ali, S., Rakha, B.A., Hussain, I., Nadeem, M.S., Rafique, M. (2013): Ecology of Feral Pigeon (Columba livia) in Urban Areas of Rawalpindi/Islamabad, Pakistan. - Pakistan Journal of Zoology 45(5): 1229 - 1234.

[2] Antczak, M. (2010): Winter Noctural Roost Selection by Solitary Passerine Bird, the Great Grey Shrike Lanius excubitor. - Ornis Fennica 87: 99 - 105.

[3] Bech, C., Reinertsen, R.E. (eds.) (1989): Physiology of Cold Adaptation in Birds. Plenum Press, New York.

[4] Bolger, D.T. (2001): Urban Birds: Population, Community and Landscape Approaches. In: Marzluff, J.M. (ed.) Avian ecology and conservation in an urbanizing world. Kluwer Academic Publ., Boston.

[5] Brambilla, M., Rubolini, D., Guidali, F. (2006): Factors affecting Breeding Habitat Selection in a Cliff-Nesting Peregrine Falco peregrinus population. - Journal of Ornithology 147: 428 - 435.

[6] Brown, R.G.B. (1969): Seed Selection by Pigeons. - Behaviour 34(3): 115 - 131.

[7] Bryant, D.M. (1997): Energy Expenditure in Wild Birds. - Proceedings of Nutrition Society 56: $1025-1039$.

[8] Chandler, C.R., Ketterson, E.D., Val Nolan, J.R. (1995). Spatial Aspects of Roost-Site Selection in Breeding Male Dark-Eyed Juncos. - The Condor 97: 279 - 282.

[9] Collett, A. (AnnelizaC@daff.gov.za) (2015): Agricultural crop list. [E-mail to:] Harris, E. (emmaharris09@gmail.com), Oct. 21.

[10] Counsilman, J.J. (1974): Waking and Roosting Behaviour of the Indian Myna. - Emu 74: $135-148$.

[11] Ditchkoff, S.S., Saalfeld, S.T., Gibson, C.J. (2006): Animal Behaviour in Urban Ecosystems: Modifications due to human-induced stress. - Urban Ecosystem 9: 5 - 12.

[12] Dobeic, M., Pintarič, S., Vlahović, K., Dovč, A. (2011): Feral Pigeon (Columba livia) Population Management in Ljubljana. - Veteinarski Arhiv 81(2): 285 - 298.

[13] Earle, R.A., Little, R.M. (1993): Hematozoa of Feral Rock Doves and Rock Pigeons in Mixed Flocks. - South African Journal of Wildlife 23: 98 - 100.

[14] Eiserer, L.A. (1984): Communal Roosting in Birds. Bird Behaviour 5: 61 - 80. 
[15] Fisher, R.J., Fletcher, Q.F., Willis, C.K.R., Brigham, R.M. 2004. Roost Selection and Roosting Behaviour of Male Common Nighthawks. - The American Midland Naturalist 151: $79-87$.

[16] Fitzwater, W.D. (1988): Solutions to Urban Bird Problems. - Proceedings of the Thirteenth Vertebrate Pest Conference 254 - 259.

[17] Giunchi, D, Baldaccini, N.E., Sbragia, G., Soldatini, C. (2007): On the Use of Pharmacological Sterilisation to Control Feral Pigeon Populations. - Wildlife Research 34: $306-318$.

[18] Giunchi, D., Albores-Barajas, Y.V., Baldaccini, N.E., Vanni, L., Soldatini, C. (2012). Feral Pigeons: Problems, Dynamics and Control Methods.- In: Soloneski, S. (ed.) Integrated Pest Management and Pest Control - Current and Future Tactics. Intech.

[19] Goodwin, D. (1983): Behaviour. - In: Wright, E.N. (ed.) Physiology and Behaviour of the Pigeon. Academic Press, London.

[20] Google Maps. (2015): University of South Africa Muckleneuk campus [Online]. Available from:https://www.google.co.za/maps/dir//-25.756165,28.200316/@ 25.7681391,28.1981992,730m/data=!3m1!1e3?hl=en. [Accessed: 05/10/2015].

[21] Gŏrski, W. (1997): Urban and Rural Populations of the Magpie Pica pica in the Koszalin Region, NW Poland. Acta Ornithologica 32: 51 - 59.

[22] Gregory, R.D., Marchant, J.H. (1995): Population trends of Jays, Magpies, Jackdaws and Carrion Crows in the United Kingdom. - Bird Study 43: 28 - 37.

[23] Haag-Wackernagel, D. (1995): Regulation of the Street Pigeon in Basel. - Wildlife Society Bulletin 23(2): $256-260$.

[24] Haag-Wackernagel, D. (1998): Ecology of Feral Pigeons in Basel, Switzerland. - In: Farina, A., Kennedy, J., Bossu, V. (eds.) INTECOL, VII International Congress of Ecology, July 19-25, 1998, Florence.

[25] Haag-Wackernagel, D. (2008): Feral Pigeon Management [Online]. Available from: www.Anatomie.unibas.ch/integrativeBiology/hag/Feral-Pigeon Strassentauben/pigeonmanagement.html [Accessed: 12/02/2013].

[26] Haag-Wackernagel, D., Bircher, A.J. (2009): Ectoparasites from Feral Pigeons affecting Humans. - Dermatology 220: 82 - 92.

[27] Haag-Wackernagel, D., Geigenfeind, I. (2008): Protecting Buildings against Feral Pigeons. - European Journal of Wildlife Research 54: 715 - 721.

[28] Haag-Wackernagel, D., Heedb, P., Leiss, A. (2006): Phenotype-dependent selection of juvenile urban feral pigeons Columba livia: Capsule we suggest the existence of colourbased selection processes on juvenile feral pigeons in an urban environment. - Bird Study 53(2): $163-170$.

[29] Hadidian, J. (2007): Wild Neighbours: The Humane Approach to Living with Wildlife. 2nd ed. - Humane Society Press, Washington DC.

[30] Hetmański, T. (2004): Timing of Breeding in the Feral Pigeon Columba livia f. domestica in Słupsk (NW Poland). - Acta Ornithologica 39(2): 105 - 110.

[31] Hetmański, T. (2007): Dispersion Asymmetry within a Feral Pigeon Columba livia population. - Acta Ornithologica 42(1): 23 - 31.

[32] Hetmański, T., Wołk, E. (2005): The Effect of Environmental Factors and Nesting Conditions on Clutch Overlap in the Feral Pigeon Columba livia f. urbana (GM.). Polish Journal of Ecology 53(4): 523 - 534.

[33] Hutton \& Rostron, (2005): Method statement for the control of feral pigeons [Online]. Available from: http://www.handr.co.uk/literature/feral_pigeons.htm. [Accessed: 05/12/2012].

[34] Hutton, T.C., Dobson, J. (1993): The Control of Feral Pigeons: An Independent Approach. - Structural Survey 11(2): 159 - 167.

[35] ICAE, (2013): About Pretoria. The 5th International Conference on Applied Energy July $1-4 \quad 2013 \quad$ [Online]. Available from: http://appliedenergy.org/2013/history/about\%20pretoria [Accessed : 19.06.2016]. 
[36] Jacquin, L., Cazelles, B., Prévot-Julliard, A., Leboucher, G., Gasparini, J. (2010) : Reproduction management affects breeding ecology and reproduction costs in feral urban pigeons (Columba livia). - Canadian Journal of Zoology 88: 781 - 787.

[37] Jokimäki, J., Kaisanlahti-Jokimäki, M., Sorace, A., Fernández-Juricic, E., RodriguezPrieto, I., Jimenez, M.D. (2005): Evaluation of the "Safe Nesting Zone" Hypothesis across an Urban Gradient: a multi-scale study. - Ecography 28: 59 - 70.

[38] Johnston, R.F. (1992a): Evolution in the Rock Dove: Skeletal Morphology. - The Auk 109: $530-542$.

[39] Johnston, R.F. (1992b): Rock Dove. - In: Poole, A., Stettenheim, P., Gill, F. (eds.) The Birds of North America. The American Ornithologists' Union, Washington.

[40] Johnston, R.F., Janiga, M. (1995): Feral pigeons. - Oxford University Press, New York.

[41] Jones, J. 2001: Habitat Selection Studies in Avian Ecology: A Critical Review. -The Auk 118(2): $557-562$.

[42] Kochert, M.N. (1972): Population Status and Chemical Contamination in Golden Eagles in Southwestern Idaho. - MSc. University of Idaho, Moscow, USA.

[43] Körtner, G., Geiser, F. (1999): Roosting Behaviour of the Tawny Frogmouth (Podargus strignides). - Journal of Zoology 248: 501 - 507.

[44] Krebs, L.B. (1974): Feral Pigeon Control. - In: Proceedings of the 6th Vertebrate Pest Conference: $257-262$.

[45] Krimowa, S. (2012): Pigeons and People: Resource Ecology and Human Dimensions of Urban Wildlife. - M.Sc. Victoria University of Wellington, Wellington.

[46] Kruger, A.C. (2004): Climate of South Africa. Climate Regions. WS45. - South African Weather Service. Pretoria, South Africa.

[47] Leonard, J.P. (1998): Nesting and Foraging Ecology of Band-tailed Pigeons in Western Oregon. - PhD Oregon State University, Oregon.

[48] Little, R.M. (1994): Marked Dietary Differences between Sympatric Feral Rock Doves and Rock Pigeons. - South African Journal of Zoology 29(1): 33 - 35.

[49] Lofts, B., Murton, R.K., Westwood, N.J. (1966): Gonadal Cycles and the Evolution of Breeding Seasons in British Columbidae. - Journal of Zoology 150: 249 - 272.

[50] Luniak, M. (2004): Synurbanization - adaptation of animal wildlife to urban development. - In: Shaw, W.W., Harris, L.K., Vandruff, L. (eds.) Proceedings of the 4th International Symposium on Urban Wildlife Conservation. Arizona, Tucson: 50-55.

[51] Martin, T.E. (1993): Nest Predation and Nest Sites: New Perspectives on Old Patterns. BioScience 43: 523 - 532 .

[52] McCollin, D. (1998): Forest Edges and Habitat Selection in Birds: A Functional Approach. - Ecography 21: 247 - 260.

[53] Mooallem, J. (2006): Pigeon Wars. - New York Times Magazine, Oct. 15: 54.

[54] Mosher, J.A., White, C.M. (1976): Directional Exposure of Golden Eagle Nests. Canadian field naturalist 90: 356 - 359 .

[55] Murton, R.K. (1966): Natural Selection and the Breeding Seasons of the Stock Dove and Wood Pigeon. - Bird Study 13(4): $311-327$.

[56] Murton, R.K., Thearle, R.J.P., Coombs, C.F.B. (1972): Ecological studies of the feral pigeon Columba livia var. 1ll. Reproduction and plumage polymorphism. - Journal of Applied Ecology 9: 841 - 853.

[57] Murton, R.K., Thearle, R.J.P., Thompson, R.J.P. (1972): Ecological studies of the feral pigeon Columba livia var. 1. Population, breeding biology and methods of control. Journal of Applied Ecology 9: 835 - 874.

[58] Ntshoe, L. (2013): Catering and Cleaning Manager, University Estates, UNISA. Personal communication.

[59] O'Regan, S.M., Flynn, D., Kelly, T.C., O'callaghan, M.J.A., Pokrovskii, A.V., Rachinskii, D. (2012): The response of the woodpigeon (Columba palumbus) to relaxation of intraspecific competition: A hybrid modelling approach. - Ecological Modelling 224: $54-64$. 
[60] Ontiveros, D. (1999): Selection of Nest Cliffs by Bonelli's Eagle (Hieraaetus fasciatus) in South-eastern Spain. - Journal of Raptor Research 33(2): 110 - 116.

[61] Philo, C., Wilbert, C. (eds.) (2000): Animal Spaces, Beastly Places: New Geographies of Human-Animal Relations. - Psychology Press, New York.

[62] Ratcliffe, D.A. (1993): The Peregrine Falcon, $2^{\text {nd }}$ ed. - Poyser, London.

[63] Robbins, C.S. (1995): Non-Native birds. - In: LaRoe, E.T., Farris, G.S., Puckett, C.E., Doran, P.D., Mac, M.J. (eds.) Our living resources: a report to the nation on the distribution, abundance, and health of U.S. plants, animals and ecosystems. Department of the Interior, National and Biological Service, Washington DC.

[64] Rose, E., Nagel, P., Haag-Wackernagel, D. (2006): Spatio-temporal use of the urban habitat by feral pigeons (Columba livia). - Behavioral Ecology and Sociobiology 60: 241 $-254$.

[65] Ryan, A.C. (2011): The distribution, density, and movements of feral pigeons Columba livia and their relationship with people. - MSc. Victoria University of Wellington, Wellington.

[66] Sacchi, R., Gentilli, A., Razzetti, E., Barberi, F. (2002): Effects of Building Features on Density and Flock Distribution of Feral Pigeons Columba livia var.domestica in an Urban Environment. - Canadian Journal of Zoology 80: 48 - 54.

[67] Seamans, T.W., Blackwell, B.F. (2011): Electric Shock Strips as Bird Deterrents: Does Experience Count? - International Journal of Pest Management 57(4): 357 - 362.

[68] Shetty, S., Bharathi, L., Shenoy, K.B., Hegde, S.N. (1992): Biochemical properties of pigeon milk and its effect on growth. - Journal of Comparative Physiology 162: 632 636.

[69] Shochat, E., Lerman, S., Fernández-Juricic, E. (2010): Birds in Urban Ecosystems: Population Dynamics, Community Structure, Biodiversity and Conservation. - Urban Ecosystem Ecology urbanecosysteme: 75 - 86.

[70] Shotter, R.A. (1978): Aspects of the Biology and Paraistology of the Speckled Pigeon Columba guinea L. from Ahmadu Bello University Campus, Zaria, North Central State, Nigeria. - Zoological Journal of the Linnean Society 62: 193 - 203.

[71] Skead, D.M. (1969). A Study of the Rock Pigeon Columba guinea. - Ostrich 42(1): 65 69.

[72] Soldatini, C., Mainardi, D., Baldaccini, N.E., Giunchi, D. (2006): A Temporal Analysis of the Foraging Flights of Feral Pigeons (Columba livia f. Domestica) from Three Italian Cities. - Italian Journal of Zoology 73(1): 83 - 92.

[73] South African Weather Service, (2010): Climate of South Africa. WB42 Climate Statistics 0513465. - University of Pretoria experimental farm, Pretoria.

[74] Stringham, S.A, Mulroy, E.E, Xing, J., Record, D., Guernsey, M.W., Aldenhoven, J.T., Osbornee, J., Shapiro, M.D. (2012): Divergence, convergence, and the ancestry of feral populations in the domestic rock pigeon. - Current Biology 22: $1-7$.

[75] Tigas, L.A., Van Vuren, D.H., Sauvajot, R.M. (2002): Behavioural responses of bobcats and coyotes to habitat fragmentation and corridors in an urban environment. - Biological Conservation 108: 299 - 306.

[76] Tsurim, I., Abramsky, Z., Kotler, B.P. (2008): Foraging Behaviour of Urban Birds: Are human commensals less sensitive to predation risk that their nonurban counterparts? The Condor 110(4): $772-776$.

[77] Van Niekerk, J.H. (2003): Grain Selection and Flocking of Rock Pigeons at a Cattle Feedlot in Gauteng Province, South Africa. - South African Journal of Wildlife Research 33(2): $138-141$.

[78] Van Niekerk, J.H. (2009): Loss of Sunflower Seeds to Columbids in South Africa: Economic Implications and Control Measures. - Ostrich 80(1): 47 - 52.

[79] Van Niekerk, J.H., Van Ginkel, C.M. (2004): The Feeding Behaviour of Pigeons and Doves on Sown Grain Crops on the South African Highveld. - Ostrich 75(1\&2): 39 - 43. 
[80] Walsberg, G.E. (1986): Thermal Consequences of Roost-Site Selection: The Relative Importance of Three Modes of Heat Conservation. - The Auk 103: 1- 7.

[81] Walsberg, G.E., King, J.R. (1980): The Thermoregulatory Significance of the Winter Roost-sites selected by Robins in Eastern Washington. - Wilson Bulletin 92: 33 - 39.

[82] Wanless, R.M., Jupiter, T.A. (2002): Predation on Doves by Pied Crows, Corvus albus, on Aldabra Atoll. - Ostrich 73(1\&2): 59 - 78.

[83] Westington, J. (2013): Pest control manager, UNISA. Personal communication.

[84] Zwartjies, P.W., Nordell, S.E. (1998): Patterns of Cavity-Entrance Orientation by Glided Flickers (Colaptes chrysoides) in cardŏn cactus. - The Auk 115: 119 - 126.

\section{ELECTRONIC APPENDIX}

This article has an electronic appendix. 